\title{
Testimony and Memory Narrative of Traumatic Events as A Way to Survive in Amy Tan's The Joy Luck Club
}

A Research Submitted by

ZeinabAbd El-Sameea’ Monir

June 2018 


\section{Abstract}

Due tothe scarcity of the studies written about testimony and memory narrative of traumatic events as a way to survive in Amy Tan's The Joy Luck Club, this research aims at identifying the term"testimony and memory narrative"from a psychological perspective. Besides, it provide an overview of her novel, The Joy Luck Club.This research uses thepsychological approach. There is no firm definition of "testimony and memory narrative", however, the researchconspicuously finds out a psychoanalytical definition of the term "testimony and memory narrative".

\section{المستخلص}

نظرًا لندرة الدراسات المكتوبة حول سرد الذكريات للأحداث الصادمة كوسيلة للبقاء

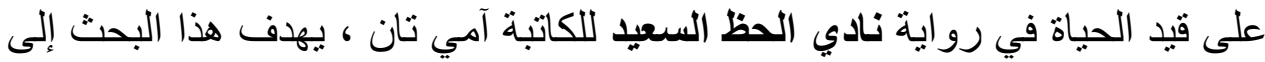
تحديد مصطلح "سرد الذكريات" من منظور نفسي ـ وعلاوة على ذلك ، يقدم هذا البحث نظرة عامة على رواية نادي الحظ السعيد مستخدماً النهج النفسي. و وعلي الرغم من أنه لا يوجد تعريف ثابت لمصطلح "سرد الذكريات"، فإن البحث يتوصل بشكل و اضح إلي تعريف النحليل النفسي لهصطلح "سرد الذكريات".

\section{Introduction}

The Joy Luck Clubintroduces the creation and transmission of a narrative that contains and makes sense of traumatic experience. This memory narrative is deemed as a 
crucial step in a survivor's potential recovery. In Amy Tan's The Joy Luck Club (1989), the Chinese American daughters feel the powerful, and usually negative, effects of traumatic events that psychically scarred their parents and grandparents.

Drawing on the theoretical frame of this research, there are many practical implications to be elaborated on. Two types of trauma are under scrutiny in this research. Psychic trauma, and diasporic trauma. These two types of trauma are explored to the selected works and trauma theory. The first type of trauma discussed is psychic trauma as represented in Tan's novel.

Tan does organize her stories coherently by connecting segments of her stories in her own way for the purpose of keeping a balance which is significant in this book. The novel consists of four sections and sixteen chapters/stories which are interwoven by eight women of two generations: four mothers and four daughters of four families. Of the four daughters, Jingmei has a special position in the novel. She acts as both mother and daughter as she says, "I am to replace my mother" (19). She tells her mother's stories, takes her mother's place at the mahjong table, and sets off to China to see the long-lost twin daughters both as mother and for her mother's wish. In this novel, Section I is made up of the four stories told by four mothers; Section II and Section III are told by four daughters; and Section IV turns back to mothers. Jing-mei is the first 
narrator as well as the last one and the last story is the continuation of the first one by the same narrator.

Additionally,The Joy Luck Club opens with a decidedly traumatic event: as Jing-mei Woo begins to narrate, she reveals that her mother, SuyuanWoo, has recently, suddenly, and unexpectedly died. The loss of her mother and her subsequent responsibility to reconnect with the twins Suyuan had to abandon in China, before immigrating, marrying Jing-mei's father, and giving birth to Jing-mei, and to impart to the twins the knowledge of their mother, results in a crisis for Jing-mei, who worries to her mother's friends, "I don't know anything. She was my mother" (31). An-mei exclaims, "Not know your own mother? ... Your mother is in your bones!" (31).

However, what distinguishes The Joy Luck Club from other novels is that it portrays characters who, because of the intense and apparently unresolved impact of traumatic events on their ancestors, must work through the powerful, sometimes overwhelming memories of their parents and grandparents without having any physical or psychological access, through their own memories to those events.

Yet, they have psychological access. In her study Family Frames: Photography, Narrative, and Postmemory (1996), Marianne Hirsch theorizes the consequences of the kind of intergenerational transmission of trauma seen in The Joy Luck 
Club through the concept of "postmemory," which she describes as more "indirect and fragmentary" (23) than the memory would have been for its original survivor. Hirsch probes that when looking at a photograph, specifically one that was taken of events or people during times preceding the viewer's birth, the viewer necessarily "fills in what the picture leaves out," so she must create an "imaginative" relationship with the memory represented by the photograph (21). Thus, when interacting with the traumatic memory of one's ancestors, a second-generation subject, always at a distance from the remembered event, will have to "fill in" or "imagine" the memory, since she has no direct access to the event itself.

Hirsch, then, defines "postmemory" as a "powerful and very particular kind of memory" that characterizes the experience of those who grow up dominated by narratives that preceded their birth, whose own belated stories are evacuated by the stories of the previous generation shaped by traumatic events that can be neither understood nor recreated (22). While postmemory may allow descendants to establish an imaginative connection with the memories of their ancestors and thus foster empathy, it is inherently more difficult for second-generation subjects to work through postmemory than it would be for them to work through traumatic events witnessed firsthand. Their distance from the scene of trauma results in their utter inability 
to ever experience or understand the horrors faced by the previous generation.

\section{Methodology of the Research}

This research uses the psychoanalytical approach to illustratehow testimony and memory narrative of traumatic events are presented as a way to survive in Amy Tan's The Joy Luck Club.This researchapplies Marianne Hirsch's theory of postmemory, which describes the inherently complex position of the descendant of survivors of traumatic events, in reading Amy Tan's The Joy Luck Club which depicts characters who must grapple with the overwhelming stories of their parents' painful memories of discrimination and diaspora.Tan's The Joy Luck Clubis selected in particular because it is deemed as a great success, according to the information offered by WendyHo: it was the longest running hardcover on The New York Times bestseller list, it gained several awards (the Commonwealth Club Gold Award, the Bay Area Book Critics Circle award, Los Angeles Times book award, etc.).

\section{Importance of the Research}

This research analyzes The Joy Luck Club in order to explore the complexity of postmemory and the multiplicity of second-generation reactions to the dominance of their ancestors' traumatic memories, while trying to understand the traumatic events and working through to survive. By reading Tan'snovel, 
we reach an understanding of the necessary conditions for working though postmemory; It indicate that, ultimately, descendants of survivors must grapple with the stories of their ancestors and understand the relationship of those stories to their own lives in order to integrate the remnants of those traumatic events into their memories in an attempt to survive. Further, by exploring how postmemory affects Tan, we can hypothesize that while each experience of postmemory is bound to culturally specific circumstances, such as the Holocaust, or World War II, postmemory is a condition with cross-cultural resonances. Although The Joy Luck Club is ultimately more hopeful about the potential for descendants to work through their ancestor's traumatic memories, it opens with a decidedly tragic event: as Jing-mei Woo begins to narrate.

This researcher's analysis of Amy Tan's novel is primarily influenced by DoriLaub's work on the position of the listener in Testimony: Crises of Witnessing in Literature, Psychoanalysis, and History; Laub emphasizes that survivors must involve a listener, one to whom the survivor "can articulate and transmit the story, literally transfer it to another outside oneself and then take it back again, inside" ("Bearing Witness" 69). Thus, the selected novel understudy is primarily a trauma narrative.

In his study Writing History, Writing Trauma, Dominick LaCapranotes that literature is the privileged means of 
expressing the inconsistencies and complexities of traumatic experience. LaCapra also suggests that Caruth is a proponent of this idea: "Many commentators would agree with Caruth in thinking that the literary (or even art in general) is a prime, if not the privileged, place for giving voice to trauma as well as symbolically exploring the role of excess" (190).

Because "literature in its very excess can somehow get at trauma in a matter unavailable to theory - that it writes (speaks or even cries) trauma in excess of theory," it may be one of the modes best suited to communicating the traumatic experience (183). Because "art departs from ordinary reality to produce surrealistic situations or radically playful openings that seem to be sublimely irrelevant to ordinary reality but may provide indirect commentary or insight into that reality," fiction is able to explore the paradoxes of trauma in interesting ways (185). It is agreed that this novel presents "surrealistic situations," but it is also true that the "surreal" qualities of this narrativehighlights the challenges faced by a survivor who attempts to transform her experience into narrative as a mode of healing.

Also, theorists of trauma and literary critics argue that Tan's novel bleakly implies that relying on physical experience eliminates the possibility of empathizing with characters and, by extension, with others in the real world. However, in her depictions of survivors' struggles to relate their experiences, 
Amy Tan does illustrate the survivor's paradoxical drive to remember and to forget, and her impossible mission to tell a story that cannot be understood; the novel provides an honest portrait of this struggle for readers, and the ironically realistic portraits of the psychology of the trauma survivors in the novel may, in fact, be the ideal method of earning the understanding of readers.Tan's contribution to Asian American literature and Asian American women's studies lies in her representation in the novel of how her female charactersare traumatized in accordance with the narratives of the novel: Tan's unique strategy of balancing sixteen monologues told by four mothers and four daughters and through the analysis of the narration, we can see the hopes that Tan has cherished in her novel.

\section{Setting the Problem of the Research}

Telling the traumatic event is a way to survive. In The Joy Luck Club, the Chinese American daughters unwittingly repeat elements of their mothers' traumatic memories, apparently due both to their lack of knowledge of their mothers' stories and to the still unresolved impact of those stories on the mothers themselves. Through their depictions of the effects of postmemory on descendants, this novel suggests that it is the traumatic memory narrative of the Hirsch points out that although she "[has] developed this notion [of postmemory] in 
relation to children of Holocaust survivors ... it may usefully describe other second-generation memories of cultural or collective traumatic events and experiences" (22).

The mothers also struggle to survive their destructive traumatic experiences. The second-generation women in Tan's novel want to distance themselves from their mothers, from Chinese history, and from those memories of events before their own births: while although the mothers in the novel pass on particularly traumatic memories of their lives in China and the struggles of their migration and life in the U.S., these memories, once they are brought to the surface, allow for increased understanding and potential healing in the mothers traumatized psyches.

Consequently, The Joy Luck Club more effectivelyprops the power of storytelling to allow mothers to work through painful traumatic memories that have, as yet, remained unresolved and may be surfacing for the first time.

It is highly important to mention in this context that Gloria Shen's "Storytelling Reconciles Mothers and Daughters" in Women's Issues in The Joy Luck Club (Ed. Gary Wiener), and Shen's longer article, "Born of a Stranger: Mother-Daughter Relationships and Storytelling in Amy Tan's The Joy Luck Club," as well as Rocio Davis' "Identity in Community in Ethnic Short Story Cycles: Amy Tan's The Joy Luck Club, 
Louise Erdrich's Love Medicine, Gloria Naylor's The Women of Brewster Place." A number of articles about a way to survive traumatic experiences. Jing-mei and the other daughters in The Joy Luck Club would likely share Marianne Hirsch's sentiment that, in relation to her parents' Holocaust memories, that she has "sometimes felt there were too many stories, too much affect, even as at other times [she's] been unable to fill in the gaps and absences" (Family Frames 244). Jing-mei recalls repeatedly hearing the story of how Suyuan founded the original Joy Luck Club in China, but it is not until the end of the novel that the fullest version of the story is revealed.

The novel's structure thus highlights Suyuan's continued presence in the novel and symbolically reveals the extent to which the memories of the mother haunt the daughter, insisting that they be confronted and resolved. Jing-mei's trip to China at the end of the novel signifies that she, as a surrogate, can potentially resolve the prevailing imbalance that marred Suyuan's life. Within her own lifetime, Suyuan attempted to deal with wartime struggles by forming a supportive community in China. As a reaction against the miserable conditions in Kweilin, a city marred by overpopulation, poverty, disease, and constant bombings by the Japanese, Suyuan began the original Joy Luck Club, a meeting of four women who congregated to talk, play games, and try to forget their traumatic experiences. 
The meetings became a ritual, allowing the women to purge themselves of their pain and look forward to a better future: "we could forget past wrongs done to us. We weren't allowed to think a bad thought. We feasted, we laughed, we played games, lost and won, we told the best stories. And each week, we could hope to be lucky. That hope was our only joy" (The Joy Luck Club 12) Thus, through their Joy Luck Club, the women try to survive their traumatic experiences.

Faced both with the traumatic memories of wartime China and the new challenges of immigration to the United States, Suyuan reinstates The Joy Luck Club with three women she meets in church. What unites the new Joy Luck Club in San Francisco is that "the women of these families also had unspeakable traumatic experiences they had left behind in China and hopes they couldn't begin to express in their fragile English" (The Joy Luck Club 6). Their "unspeakable" memories have apparently remained unspoken, particularly to their daughters. Due to Suyuan's attempts to present the positive side of her experiences and the difficulty of relating traumatic memories, Jing-mei did not know for years that her mother's Chinese life was marked by another "unspeakable tragedy."

Although Jing-mei had heard her mother's story many times and assumed it was "a Chinese fairy tale" (12), on one occasion, her daughter's selfish, childish behavior motivates 
Suyuan's much darker version of this testimony. Suyuan reveals that, when fleeing from Kweilin to Chungking, she had to leave everything she had been carrying on the side of a road, including her infant twin daughters. It is interesting to note that Suyuan's testimony is characterized by its repetition; as Catherine Romagnolonotes, "Suyuan attempts to recover her whole self by repetitively beginning her originary story" (101).

In order for Jing-mei to fill Suyuan's place, she must come to know more intimately her mother's formative memory. A later testimony by Canning Woo, Jingmei's father, fills in more of the details, such as the fact that Suyuan was "delirious with pain and fever," physically exhausted and bleeding from carrying clothes and food.

Further, the continuous growth of the story represents the way in which Suyuan's memory becomes more detailed each time she tells the story. Her testimony cannot be given all at once; rather, like the memory itself, her narrative is fragmented and continually in process. The fact that she had not, in the innumerable versions of the story given to that point, told Jingmei the true ending of the story shows that it has taken time for Suyuan to reach a point at which she can narrate the most painful part of that memory. Her sudden death, before hearing from or meeting her long-lost daughters, inhibits Suyuan from gaining any sense of closure; thus, Tan has Jing-mei take on the 
responsibility of resolving, to the extent that it is even possible, her mother's unfinished story. What Suyuan may perceive to be a language barrier keeping her from expressing her story and telling it to Jing-mei is also characteristic of the testimony of trauma. Laub argues, "There are never enough words or the right words, there is never enough time or the right time, and never enough listening or the right listening to articulate the story that cannot be fully captured in thought, memory, and speech" (63).

They are frightened. In me, they see their own daughters, just as ignorant, just as unmindful of all the truths and hopes they have brought to America ... They see daughters who will bear grandchildren born without any connecting hope passed from generation to generation. (The Joy Luck Club 31)

Huntley describes the three mothers' stories in "Feathers from a Thousand Li Away," the first section of the novel, as revealing "the trauma of a long-ago pivotal event that transformed a naïve young girl into a self-directed woman" (50). These initial stories by Lindo, An-mei, and Ying-ying give priority to a particular moment or event from their childhood/adolescence in China, which Tan ultimately connects to similar events in the daughters' lives, demonstrating the impact of postmemoryon the Joy Luck daughters. The most 
valuable lesson from Lindo's testimony, the ability to empower herself through narrative - has resonances not only for her daughter Waverly, but also for the other mother-daughter pairs in the novel.

Moreover, ZenobiaMistri, in “June's Symbolic Journey to Discover Her Ethnic Identity," (Women's Issues in The Joy Luck Club. 51-59), describes the novel as "an implicit conversation among the four mothers and their daughters as they tell their stories" (52). The notion that the mothers and daughters tell the stories to each increased knowledge about one another's histories and memories. Faced with Lena's marital struggles, Ying-ying sees a reflection of her own marriage because Lena has disappeared to Harold just as Ying-ying has gradually become a "ghost" in America; Ying-ying now knows she "must tell [Lena] everything about [her, Ying-ying's] past. It is the only way to penetrate her skin and pull her to where she can be saved" (The Joy Luck Club274). She knows also that she must remember her own past in order to transmit it to Lena, so Yingying grapples with her painful memories and through her own process of testimony, she is able to reclaim her identity as a "Tiger." She understands she must confront her traumatic memories, explaining:

I will gather together my past and look. I will see a thing that has already happened. The 
pain that cut my spirit loose. I will hold that pain in my hand until it becomes hard and shiny, more clear. And then my fierceness can come back. (286)

Keeping their private pains secret for years, the Joy Luck mothers have tried to protect their daughters from the trauma they experienced, particularly while in China. As the opening vignette of the novel, establishes, the Chinese mothers want to pass on to their American daughters "all [their] good intentions" (4) so that the daughters "will always be too full to swallow any sorrow" (3).Wendy Ho observes, "They want their Chinese American daughters to have the best life, not to duplicate the sad, tragic, or restricted lives they and their mothers have known" (60).

However, preceding the first section of the novel is a short vignette about a Chinese woman emigrating to the U.S. who wants to bring a swan with her, symbolic of the possibilities that this new country will represent for her daughter; the swan is "a creature that became more than what was hoped for" (3). Unfortunately, immigration officials take the swan away and the mother is left with only a feather. She now realizes that she can only tell her daughter about this experience, but she wants to wait until she can "tell her daughter this in perfect American English" (4). The mothers come to 
understand, partially through revisiting the memories of their own relationships with their mothers and by understanding how those memories have affected them throughout their lives, that the daughter must know the mother's stories, even though many of their memories are traumatic.

The mothers believe that they are drifting farther away from their daughters: "They see that joy and luck do not mean the same to their daughters, that to these closed American-born minds 'joy luck' is not a word, it does not exist. They see daughters who will bear grandchildren born without any connecting hope passed from generation to generation" (31). However, what makes them survive is their memory narrative.

It is important to realize that while the novel "invests narrative with tremendous representational power" and depicts storytelling "as a means of recovering the past and fostering communication between mothers and daughters" (Singer 334), Tan's novel encourages us to see Jing-mei's connection to the twins as the closest reconciliation that can be expected. Meanwhile, the other mother-daughter pairs have the opportunity to share more of themselves and their memories. Although the feeling of impossibility persists under the novel's surface, Joy Luck's bittersweet ending is tempered with hope and the possibility of healing traumatic experiences through memory narrative. 
The condition of possibility associated with traumatic memory narrative and, more appropriately for it, with postmemory. Tan's novel is centrally concerned with the effects of parents' memories on their children. While The Joy Luck Clubhighlights, arguably, much different accounts of the workings of postmemory, one value of reading this text is that we are able to see the variety of experiences of second generation survivors of trauma and the difficulties associated with this particular type of traumatic memory.

The Joy Luck Club seems to end with a tentative resolution, each novel actually depicts both the hardships faced by those suffering from the effects of postmemory and the hope and desire for working through that persists despite the difficulties inherent in the process of working through any trauma, let alone a trauma not experienced firsthand. The Joy Luck Club suggests that the narration of memory by parent to child is a necessary step in the process of working through as a way to survive.

Always sensitive to the inherent difficulty in coping with postmemory, Hirsch describes second-generation survivors as in exile, existing in a diasporic state:

The children of exiled survivors, although they have not themselves lived through the trauma of banishment and forceful separation 
from home and the destruction of that home, remain marked by their parents' experiences: always marginal or exiled, always in the diaspora ... This condition of exile from the space of identity, this diasporic experience, is a characteristic aspect of postmemory. (243)

This condition of exile is one that is deeply felt by both the Chinese and Chinese American characters in The Joy Luck Club, who are removed from the physical landscape of their parents' memories as well as from the memories themselves, but who "remain marked" by trauma and thus must also work through and mourn the original loss and the necessary absence that occurs with postmemory. Despite the seeming impossibility of the position of postmemory, Hirsch emphasizes that an "aesthetics of postmemory ... needs simultaneously to (re)build and to mourn" (245). Tan's novel ultimately indicates that working through will always be a continuous, difficult process for survivors and their children, but also provides, even if subtly, the opportunity for change, reconciliation, and healing past traumatic experiences.

In Tan's The Joy Luck Club, Suyuanis forced to obey the patriarchal code, learning to swallow her bitterness and tears since she is, unfortunately, born a girl. As a daughter of a wealthy family, she is spoiled; but as a female, she is restricted and controlled by the patriarchal society. 
For example, Suyuan's family rule is, "Only one kind of daughter can live in this house, obedient daughter" (153). Anmei has tried to make her daughter listen to her for "[m]ore than thirty years" (208). She argues, "You only have to listen to me" because "mother is best" $(208,210)$. And Lindo believes the Chinese character includes "How to obey parents and listen to your mother's mind. How not to show your own thoughts, to put your feelings behind your face" (289).

Tan introduces another example of traumatic rape, in The Joy Luck Club, An-mei's mother at first takes it as her "fate" to become $\mathrm{Wu}$ Tsing's concubine after she is raped by this evil man. Nobody believes her story including her own family and she is simply driven out of the house by her own mother. Furthermore, in old China the only thing the raped widow could do was to commit suicide. This no name woman takes it as her "fate" because her mother tells her the story of the turtle, teaching her to "swallow your own tears" (244). However, this no name woman finally kills herself as a resistance against patriarchy: "she would rather kill her own weak spirit so she could give me a stronger one" (271). "And on that day, I learned to shout" (272). The mother kills herself for her daughter to rise up; the mother transfers her resistance against patriarchy to her daughter in the only way she can think of; the mother challenges 
the men's world by sacrificing her own life for a hope that her daughter can live a better life.

This researchis carried out through the lens of contemporary theories of trauma, tracing the ways in which survivors struggle to construct narratives that contain and make sense of their experiences. Many of the major theorists of trauma studies emphasize the impossibility of re-capturing traumatic events through creating narratives even while recognizing that the survivor's need to tell her story persists. This research, however, explores the ways in which Tan's selected extend theories that insist too readily on the survivor's inability to accurately or completely re-member by depicting characters who, despite difficulty, present narrative accounts of their painful memories. Through a close reading of Tan's novel, I emphasize that the complexities highlighted by this text ultimately foster our deeper understanding of the traumatized subject and her attempts to empower herself through testimony.

Since a number of writers, critics, and academicians concur that feminist criticism has its roots in feminist theory, it is important to establish a working definition of feminism. Again, a common definition is difficult to recognize since there exist nearly as many definitions as critics.

The point of agreement among the seemingly myriad of theories of contemporary American feminism is a recognition 
that women in American society share a "disjunction" separating them, as feminine, from the common culture (Hunt 11). Feminist theorists as diverse as JosephineDonovan, Ling, Mary Daly, Ann Wilson Schaef, and Merle Woo recognize that women's experiences are defined as outside the realm of relevant experiences, outside a reality determined, more precisely, as male reality. Such theorists acknowledge that, for men and women alike, women are always Simone de Beauvoir's "Other" (29). Donovan calls much feminist literary criticism "corrective criticism." She sees the goal of this criticism as, generally, focusing the theoretical spotlight on "feminine" reality and, specifically, correcting the male bias feminist theorists believe pervades literary criticism (Crit. Ing. 605).

ElaineShowalter finds out the same conclusion in her description of feminist criticism as an act of rebellion against existing male critical theory. Here, she insists that feminist criticism should be based more on women's studies than on English studies (460) and asserts that feminist studies reject supposedly objective standards of literary criticism based on the male canon and male criticism in favor of accepting the "authority" of female experience (458).

Western feminist theories of Simone de Beavoir and Kate Millett and Asian American feminist theories of King-Kok Cheung and Elaine Kim are used to deal with the issues of 
Chinese American women and their demand for freedom from sexual oppression and for their rights as both Asian Americans and as women. Judith Butler's theory on gender is used to demonstrate the efforts that Asian American women writers such as Tan has made to problematize the gender definition and gender division in their works.

Amy Tan became famous because, as Wendy Ho concludes, Tan "captured the attention of not only a mainstream audience but also an Asian American female readership" (In Her Mothe's House 44).

From this theoretical base, then, it is a short step to a theory of feminist criticism as, first, a recognition of the validity of women's experiences as well as of whatever mode women use to convey their originality, their uniqueness, and their genuine thoughts (Showalter 461, 473). Alice Walker pays moving tribute to this individuality in general, and to her own mother's in particular, in her widely cited "In Search of Our Mothers' Gardens" (231-243). Donovan goes beyond reverence for this recognition of women's experiences to call the study of women's literature "empowerment" (Donovan FLC, xiii).

Eagleton concurs, asserting of the feminist critic, "She also believes that gender and sexuality are central themes in literature and other sorts of discourse, and that any critical account which suppresses them is seriously defective" (209). 
This research affirms the importance of bringing strong motherdaughter relationships to light once again. It is said that it is "crucial" to put women's stories in writing, especially stories of ethnic American women and of the relationships between ethnic American mothers and daughters (146). Besides Karen Elias-Button says the source of women's self-discovery is a "personal" as well as a "mythological" reexamination of women's relationships, not just with their mothers, but with the mythological figure of the mother-archetype as well (193). Tan's characters in The Joy Luck Club discover new strength and vitality within their own mother-daughter ties.

The message implied in her essay is that literature portraying similar bonds is rarely valued in modern American culture because such woman-to-woman relationships are rarely appreciated (5-14). Daly says, much more emphatically, that "feminism releases the inherent dynamic in the mother-daughter relationship toward friendship, which is strangled in the malemastered system" (G/E 39).

If Daly further defines feminism as "the journey of women becoming," (G/E 1), then feminist literary criticism could be named the analysis of women's writing that reveals the story of women becoming.

Archaeologists are now reconstructing ancient stories and myths that celebrate the power and sensuality and sacredness of 
women, as females, as sexual beings, and as mothers and daughters (Gadon 285-307). Donovan believes that power and politics are embedded in all of our actions (x). In The Joy Luck Club, Amy Tan empowers women through the resolution of paradox and the creation of myths that serve today's ethnic American women.

Tan strategically starts and ends her novel with Jing-mei as a narrator. The process toward the balance starts when she begins to take her mother's place at the mahjong table, "Without having anyone tell me, I know her corner on the table was the East. The East is where things begin" (22). She begins to understand her mother as she sits in her mother's place at mahjong table. As she finally reunites with her family-her twin half-sisters - she completes her mother's story, which begins in China, and she also integrates her own. Above all, she understands what it means to be Chinese: "The minute our train leaves the Hong Kong border and enters Shenzhen, China, I feel different. I can feel the skin on my forehead tingling, my blood rushing through a new course, my bones aching with a familiar old pain. And I think, my mother was right. I am becoming Chinese" (306). The ending of the novel suggests.

Throughout the novel, the mothers often use storytelling to heal "past experiences of loss and separation; it is also a medium for rewriting stories of oppression and victimization 
into parables of self-affirmation and individual empowerment" (Cheung 607).

The "words exchanged between the sisters are to satisfy their mother's hunger. On the contrary, the sisters have trouble communicating due to language barriers. June Woo says: "And although we don't speak, I know we all see it: Together we look like our mother. Her same eyes, her same mouth, open in surprise to see, at last, her long cherished wish." (288). Indeed, the mother's mouth remains open in this scene indicating a facial expression that alludes the desire to speak and eat: an expression linked to the Hungry Ghost. Even during her life, Suyuan acted as if she was an insatiable Hungry Ghost."

\section{Results}

Utterly,this research finds out thatTan is exceedingly aware of the power of narratives, and although postmemory is characterized by impossibility and exile from the site of memory, both novels offer opportunities for recovery and survive because Tan recognizes the therapeutic potential of narrative. In examining the role of the listener in the narrative testimony as an essential component of the recovery process, this research also pairs two novels that, on the surface, seem to present contradictory depictions of the possibility of recovery after destructive trauma. 


\section{Works Cited}

Cheung, King-Kok. "Art, Spirituality, and the Ethnic of Care:

Alternative masculinities in Chinese American Literature." Masculinity Studies \& Feminist Theory: New Directions. Ed. Judith Kegan Gardiner. New York: Columbia UP, 2002. 261-89.

Donovan, Josephine. Feminist Literary Criticism: Explorations in Theory. 2nd ed. N.p.: U P of Kentucky, 1989.

Hirsch, Marianne. Family Frames: Photography, Narrative, and Postmemory. Cambridge, MA: Harvard UP, 1997.

Ho, Wendy. In Her Mother's House: The Politics of Asian American Mother-Daughter Writing. Walnut Creek: Altamira, 1999.

Huntley, E.D. Amy Tan: A Critical Companion. Westport: Greenwood Press, 1998. 
LaCapra, Dominick. "Trauma, Absence, Loss.” Writing History, Writing Trauma. Baltimore: Johns Hopkins UP, 2001.

Laub, Dori. "Bearing Witness, or the Vicissitudes of Listening".

Testimony: Crises of Witnessing in

Literature,Psychoanalysis, and History. Eds.

ShoshanaFelman and DoriLaub. New York: Routledge, 1992.

Mistri, Zenobia. "June's Symbolic Journey to Discover Her Ethnic Identity." Women's Issues in Amy Tan's The Joy Luck Club. Ed. Gary Wiener. Farmington Hills: MI, Greenhaven Press, 2008. 51-59.

Romagnolo, Catherine. "Narrative Beginnings in Amy Tan's The Joy Luck Club: A Feminist Study." Studies in the Novel 35.1 (Spring 2003): 89-107.

Showalter, Elaine. "Feminist Criticism in the Wilderness." Contemporary Literary Criticism: Literary and Cultural Studies. Ed. Robert Con Davis and RondaldSchleifer. New York: Longman, 1989. 457-77. 
Singer, Marc. "Moving Forward to Reach the Past: The Dialogics of Time in Amy Tan's The Joy Luck Club.” Journal of Narrative Theory. 31.3 (Fall 2001): 324-352.

Tan, Amy. The Joy Luck Club. New York: Ivy Books, 1989. 